\title{
Efficacy of Toltrazuril $5 \%$ Suspension against Eimeria bovis and Eimeria zuernii in Calves and Observations on the Associated Immunopathology
}

Nicholas N. Jonsson' $(\bowtie)$, Emily K. Piper², Christian P. Gray², Abdulkerim Deniz², Constantin C. Constantinoiu ${ }^{4}$

${ }^{1}$ College of Veterinary, Medical and Life Sciences, University of Glasgow, Bearsden, Scotland, UK

${ }^{2}$ School of Veterinary Science, University of Queensland, Brisbane, Australia

${ }^{3}$ Bayer Animal Health, Leverkusen, Germany

${ }^{4}$ School of Veterinary and Biomedical Sciences, James Cook University, Townsville, Australia

E-mail: nicholas.jonsson@glasgow.ac.uk

\begin{abstract}
16 calves were each infected with suspensions containing a mixture of approximately 230,000 Eimeria bovis and 70,000 E. zuernii oocysts, which resulted in detection of oocysts in faeces of 12 of 16 calves by day +14 after infection. On day +14 after infection calves were either treated $(n=8)$ with toltrazuril at $15 \mathrm{mg} / \mathrm{kg}$ body weight or with a placebo. Observations were made on the clinical condition, faecal score and liveweight of calves daily from one day post infection (pi) until 24 days pi when all calves were euthanised and examined post mortem. Samples were collected from ileum and colon for histological, immunohistochemical and gene expression studies. The study demonstrated an efficacy of toltrazuril for the treatment of $E$. bovis
\end{abstract}

and E. zuernii infections in calves reaching $99 \%$ (based on arithmetic mean oocyst counts in faeces) within three days of treatment and remaining at or above this level for six days. Toltrazuril did not have a significant effect on the pattern and extent of immune cellular infiltration in the mucosa of ileum and colon, but the expression of the genes coding IL-2, IL-10 and TNF- $\alpha$ in the ileum and TNF- $\alpha$ in the colon were elevated in calves treated with toltrazuril. Higher levels of oocyst shedding were significantly associated with lower expression of genes coding for IL-2, IL-10 and higher IP-10. It is concluded that toltrazuril is effective for the treatment of coccidiosis due to $E$. bovis and $E$. zuernii in calves and enables the development of a normal or enhanced immune response to infection. 


\section{Introduction}

Eimeria bovis and E zuernii are the economically most important of the twenty-one or so coccidial species infecting cattle (Daugschies and Najdrowski 2005). The organisms are ubiquitous and the vast majority of cattle are exposed to them at some time in their lives (Bürger 1983). Whether exposure is followed by diarrhoea, dysentery, dehydration, debilitation or death is likely to be dependent on the timing of exposure to and the dose of the protozoan, together with the presence or absence of acquired immunity (Jonsson and Gray 2007).

The bovine immune response to infection with Eimeria seems to follow a sequential Th1 then Th2 pattern, although the effector mechanism that confers resistance in previously exposed calves remains elusive (Sühwold 2010). In 1999, Hermosilla et al. demonstrated elevations of CD4+ lymphocytes in the circulation and lymph nodes of primarily infected calves. Taubert et al. (2009) have subsequently shown that early primary infection is characterised by IFN- $\gamma$ and IL- 2 production by lymphocytes, while later phases are characterised by IL- 4 . In their study, there was no evidence of any memory-associated Th1 reactions to challenge infections. The same group (Sühwold et al. 2010) has also shown that after an initial expansion of CD4+ T cells and $\gamma \delta+\mathrm{T}$ cells in the gut of animals after primary infection there was no increased infiltration of either cell type after challenge infection.

The phagocytosis of Eimeria by macrophages has also been clearly demonstrated in cattle, independent of the presence of immune serum (Behrendt et al. 2008) and augmented by immune serum (Taubert et al. 2009). More recently, the roles of neutrophils in resistance to bovine Eimeria were shown to include neutrophil extracellular trap (NET) activity on sporozites of E. bovis with subsequent decreased parasite infectivity in vitro (Behrendt et al. 2010). However, the roles of neutrophils and macrophages have not been demonstrated in infection and challenge studies with naive animals.

Toltrazuril has been shown to be an effective agent for controlling coccidiosis in calves at a concentration of $15 \mathrm{mg} / \mathrm{kg}$ liveweight (Mundt et al. $2005 \mathrm{a}, \mathrm{b}$ ) and at $20 \mathrm{mg} / \mathrm{kg}$ liveweight (Bohrmann 1991). It acts on all intracellular forms of the parasite, primarily by interfering with cellular respiration and pyrimidine synthesis (Harder and Haberkorn 1989). The possible effect of toltrazuril on immune function has previously been investigated by Grief (2000) in poultry and by Steinfelder et al. (2005) in mice. In both cases, it was found that toltrazuril did not interfere with the development of normal immunity, and Grief (2000) demonstrated enhanced antibody production following toltrazuril treatment. However, no data are yet available regarding the effect of toltrazuril on immunity to coccidial infection in cattle. This is an important consideration because if treatment did interfere with the acquisition of immunity following initial exposure, it is possible that severe disease might follow subsequent re-exposure.

The purpose of the present study was to evaluate the efficacy of Baycox ${ }^{\circledR}$, containing a $5 \%$ suspension of toltrazuril against Eimeria bovis and E. zuernii and to compare the enteric immune response to infection in treated and untreated calves using immunohistochemistry and gene expression of cytokines and chemokines.

\section{Materials and methods}

The trial was conducted between 2 April 2007 and 24 May 2007 and was a fully randomised block design with a negative control.

\section{Animals}

Twenty-five clinically normal Bos taurus dairy and beef calves of mixed sex and aged between two and four weeks from properties with no known history of coccidiosis problems were used for the study. All calves were declared by vendors not to have previous 
treatments with coccidiostats or sulphonamides. Upon introduction to the animal house (day -25), faecal samples collected from trial calves were tested by flotation tests to confirm freedom from infections with Eimeria spp. Of the 25 calves, 16 were to be used in the study and the others were to be enrolled in the event that coccidiosis was diagnosed in one or more of the other calves and to ensure that 16 uninfected, similar calves were available.

\section{Animal housing and management}

Under-cover calf pens of $2.5 \mathrm{~m} \times 2.0 \mathrm{~m}\left(5.0 \mathrm{~m}^{2}\right)$ were used for the study, with one calf housed in each pen. The flooring was of $5 \mathrm{~mm}$ woven steel mesh with $20 \mathrm{~mm}$ openings, raised $70 \mathrm{~mm}$ from the underlying concrete floor. The sides of the pens were $1.1 \mathrm{~m}$ high, with the lower $80 \mathrm{~cm}$ made of heavy galvanised $3-\mathrm{mm}$ wire mesh with $45-\mathrm{mm}$ square openings allowing complete visibility between adjacent pens and allowing between-animal contact. Pens were hosed out completely once every day.

Calves were attended every morning between 07:00 and 08:30 $\mathrm{h}$ and every evening between 18:30 and 20:30 h. For the first week (until day -18), the calves were fed a commercial milk replacer at a rate of 21 morning and afternoon. They were also offered pellets and lucerne chaff. From day -18 onwards, calves were given $2.5 \mathrm{l}$ of milk replacer every morning. After drinking their milk, they were given lucerne chaff, with $250 \mathrm{~g}$ of commercial $15 \%$ protein heifer-rearing pellets. These pellets were free of any monensin or other pharmaceuticals. Every evening, the bucket was topped up with lucerne chaff and calves were given another $250 \mathrm{~g}$ of pellets. Water was constantly available in buckets suspended in the pens. Water was emptied and replaced every morning and every evening.

\section{Source of oocysts and preparation of infective doses}

Faecal samples were obtained from some sick and some apparently healthy calves on a cattle property near Brisbane, Queensland, Australia, where there was an outbreak of clinical coccidiosis and in which $E$. bovis and E. zuernii were confirmed to be involved on the basis of morphology of oocysts post sporulation. After confirmation of infection by qualitative faecal flotation in saturated $\mathrm{NaCl}$, oocyst counts were conducted to provide a semi-quantitative estimate of burden. Samples were mixed $1: 1$ with a $2 \%$ solution of $\mathrm{K}_{2} \mathrm{Cr}_{2} \mathrm{O}_{7}$ and transported to the Animal Research Institute (DEEDI, Queensland Government) for sporulation and separation using DEEDI standard operating procedures (Jorgensen et al. 1997). This yielded aliquots of $20 \mathrm{ml}$ with 2,500 oocysts/ml and $4 \mathrm{ml}$ with 7,000 oocysts/ $\mathrm{ml}$. This equated to a total of $44,000 \mathrm{E}$. bovis oocysts and 34,000 E. zuernii oocysts, insufficient to infect all 16 calves. Two $20-\mathrm{ml}$ doses were therefore prepared for passaging and amplification in two naive calves. Each one of the two calves was infected with approximately 22,000 E. bovis and 17,000 E. zuernii by mouth on day -20 . By day -5 , these calves were shedding sufficient oocysts to prepare the specified infective doses for all of the calves in the study.

A slightly different procedure was used to prepare the infective doses for the 16 trial animals. The two calves used for passage began to shed oocysts by day -12 and day -11 . Faecal samples were collected from these calves daily until day -4 , stored in large 2-l jars in an incubator at $27^{\circ} \mathrm{C}$ and $90 \%$ $\mathrm{RH}$, with lids loosely screwed, with equal volumes of a $2 \%$ solution of $\mathrm{K}_{2} \mathrm{Cr}_{2} \mathrm{O}_{7}$ to induce sporulation. Degree of sporulation, species breakdown and total oocyst counts were undertaken on these samples each day until it was considered that there were sufficient sporulated oocysts to infect all calves by day -1 . At this time, samples were pooled in a large 3-1 glass container and thoroughly mixed. The oocyst density of this bulked sample was $807 \mathrm{E}$. bovis/ml and 716 E. zuernii/ml. This was expected to produce 16 doses each containing 111,000 E. bovis and 98,000 E. zuernii. To remove excess $\mathrm{K}_{2} \mathrm{Cr}_{2} \mathrm{O}_{7}$, the bulked faecal suspension of about 2.21 was decanted with intermittent, thorough mixing into $50-\mathrm{ml}$ centrifuge tubes and then spun in a centrifuge at 2,000 rpm for 10 minutes. Supernatant was checked 
to ensure that there were no oocysts, before being poured off. The pellet was resuspended in distilled water and centrifuged again, before being finally resuspended in water. The contents of three 50-ml centrifuge tubes per calf were poured into $150-\mathrm{ml}$ plastic containers for storage overnight until administration. A system of allocation was employed to ensure that each dose of oocysts was drawn from early, middle and late decanted aliquots. The oocyst content of four prepared doses was checked using a semi-quantitative flotation procedure, and results are shown in Tab. 1. These estimates differed from expected numbers of 111,000 E. bovis and 98,000 E. zuernii, but were considered to provide a substantial challenge with each of the species. On day 0 , after 25 days of acclimatisation, each calf was given approximately $150 \mathrm{ml}$ of faecal oocyst suspension mixed thoroughly in its morning milk feed. No calves refused the milk and none had to be force-fed.

\section{Allocation to groups and treatments}

Calves were allocated to groups on day +14 . After feeding, calves were weighed and the weights recorded. Animals were ranked by weight, from highest $(69.5 \mathrm{~kg})$ to lowest $(49.0 \mathrm{~kg})$. A coin was flipped to allocate the first animal (heads being treatment, tails being control). Each calf by weight rank order was subsequently assigned to an alternate group. Calves were not moved from the pens that they had previously occupied to minimise social stress. Calves in the negative control group were treated with water at an equivalent dose rate per $\mathrm{kg}$ body weight as the study formulation. Calves in the treatment group were treated with the test formulation of toltrazuril (Baycox ${ }^{\circledR} 5 \%$, Bayer Animal Health GmbH, Leverkusen, Germany) at $15 \mathrm{mg} / \mathrm{kg}$ body weight $(0.3 \mathrm{ml}$ formulation $/ \mathrm{kg})$ according to the manufacturer's instructions. On day +24 , all 16 infected calves were euthanised with pentobarbitone sodium $325 \mathrm{mg} / \mathrm{ml}$ (Lethabarb, Virbac Australia, $1 \mathrm{ml} / 2 \mathrm{~kg}$ ) by jugular intravenous injection, and post-mortem gross pathological findings were recorded, with particular attention to lower small intestine and the colon. Samples of jejunum, ileum and colon were quickly collected (within 15 minutes after euthanasia) and stored in either formalin or frozen in liquid nitrogen for gene expression and immunohistochemistry/histology.

\section{Observations of liveweight and faecal consistency}

Calves were weighed on six occasions during the study period. Throughout the trial, faecal consistency was observed and recorded for faecal samples passed in the pen at the morning feeding. The faecal scoring system was based on the scale used by Mundt et al. (2005a) as follows:

$\begin{array}{ll}1 & \text { Normal to pasty } \\ 2 & \text { Semi-liquid to liquid } \\ 3 & \text { Watery } \\ 4 & \text { Haemorrhagic and/or with tissue }\end{array}$

\section{Faecal oocyst counts and differentiation}

Faecal oocyst counts with morphological differentiation (Eckert et al. 1995) of the major species were performed on six occasions at weekly intervals prior to treatment with toltrazuril, after which they were conducted daily until euthanasia. For semi-quantitative assessment of faecal oocyst counts, $2.0 \mathrm{~g}$ of faeces was weighed into a clean jar and homogenised with a small volume of $31.5 \%$ sodium nitrate $(\mathrm{SG}=1.3)$, strained through

Tab. 1 Estimated sporulated oocyst counts in four pre-prepared doses administered to calves

\begin{tabular}{|c|c|c|}
\hline Sample & E. bovis estimated total count & E. zuernii estimated total count \\
\hline 1 & 225,000 & 75,000 \\
\hline 3 & 315,000 & 75,000 \\
\hline 9 & 225,000 & 75,000 \\
\hline 14 & 165,000 & 45,000 \\
\hline
\end{tabular}


a $0.15-\mathrm{mm}$ sieve and made up to a volume of $60 \mathrm{ml}$. While agitating the solution, a small aliquot was aspirated into a transfer pipette, which was immediately held sideways and deposited in a Whitlock chamber. The oocysts in two sections, each of $0.15 \mathrm{ml}$, were counted for each sample. The number of oocysts/g was estimated by the following equation: $\mathrm{OPG}=($ count $/ 0.3 \mathrm{ml}) \times 60 \mathrm{ml} / 2 \mathrm{~g}$, which rounds out to $\mathrm{OPG}=$ count $\times 100$.

Oocyst species differentiation was performed after sporulation for preparation of the infective doses, and without sporulation in the later stages of the trial, when oocyst species counts were required. Sporulation was induced by mixing with an equal volume of $2.0 \% \mathrm{~K}_{2} \mathrm{Cr}_{2} \mathrm{O}_{7}$ and incubation at $27^{\circ} \mathrm{C}$ and $95 \% \mathrm{RH}$. Differentiation was based on the illustrations and key/criteria described in the ADAS Manual of veterinary parasitological laboratory techniques (1971) and by Eckert et al. (1995).

\section{Post-mortem examinations}

Post-mortem examinations were conducted immediately after confirmation of death. An incision was made in the ventral midline and the abomasum, small intestine, caecum and colon were exteriorised. Digital photographs were taken immediately after exteriorisation of the gut to demonstrate the overall degree of serosal injection or hyperaemia. Sections (approximately $300 \mathrm{~mm}$ ) of each of the jejunum, the ileum and the colon were removed, opened longitudinally and arranged on the table for photographing and description. These sections were examined for signs of serosal surface injection, mucosal hyperaemia and mucosal erosion or nodularity, and each of the parameters was scored on a 0 -to- 3 scale as below:

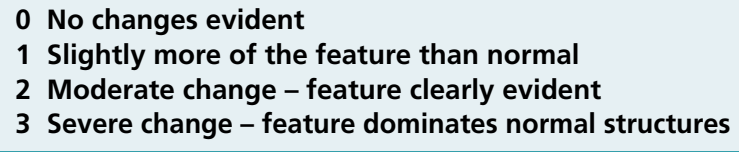

Qualitative observations were also recorded where appropriate. Biopsy samples measuring approximately $5 \mathrm{~mm}$ x $5 \mathrm{~mm}$ were cut from the jejunum, ileum and colon and each one stored in $10 \%$ formal saline and liquid nitrogen.

\section{Immunohistochemistry}

The immune cells infiltrating the intestine were identified by double immunofluorescence labelling and Haematoxilin and Eosin staining (H\&E). For immunohistochemistry, cryosections, $6 \mathrm{~mm}$ thick, cut from the intestine samples were mounted on Superfrost ${ }^{\circledR}$ Plus glass slides (Menzel-Glaser, Braunschweig, Germany) and dried overnight at room temperature (RT) using a fan. The sections were fixed in cold ethanol $\left(4^{\circ} \mathrm{C}\right)$ for $8 \mathrm{~min}$ and washed three times in phosphate-buffered saline (PBS, $137 \mathrm{mM} \mathrm{NaCl}, 2.7 \mathrm{mM} \mathrm{KCl}, 8.1 \mathrm{mM} \mathrm{Na}_{2} \mathrm{HPO}_{4}$ and $1.4 \mathrm{mM} \mathrm{KH}_{2} \mathrm{PO}_{4}$ ) at room temperature (RT). Next, the cryosections were incubated overnight at $4{ }^{\circ} \mathrm{C}$ in a humidified chamber with monoclonal antibodies for specific leukocyte receptors (Tab. 2) diluted in $1 \%$ [w/v] BSA/PBS. Negative control slides were similarly incubated with $1 \%$ [w/v] BSA/PBS. After washing with PBS, the cryosections were incubated with goat anti-mouse isotype-specific antibodies conjugated with fluorescein isothiocyanate (FITC) or Texas Red (Invitrogen, Carlsbad, California, USA) $1 / 400[\mathrm{v} / \mathrm{v}]$ in $1 \%$ [w/v] BSA/PBS for $40 \mathrm{~min}$ at RT. After washing with PBS, the nuclei were stained with DAPI dilactate (Invitrogen, Carlsbad, California, USA) and the slides mounted with buffered glycerol. The slides were examined and photographed using an epifluorescent microscope (Axio Imager.Z1, Zeiss, Germany), equipped with a digital camera (AxioCam MRm, Zeiss, Germany). For H\&E staining, cryosections cut and dried similarly to those described above were fixed in $10 \%$ buffered formalin prior to staining.

\section{Enumeration of cells}

Fluorescently (FITC or Texas Red) labelled cells as well as eosinophils (as visualised after H\&E staining) infiltrating the intestine were enumerated in one slide for each animal. For all cell subpopulations except MHC class II-expressing cells, the labelled cells were manually counted in 12 randomly chosen 
Tab. 2 Monoclonal antibodies used to characterise the cells of the epithelium and lamina propria in ileum and colon

\begin{tabular}{|c|c|c|c|c|c|c|}
\hline $\begin{array}{l}\text { Monoclonal } \\
\text { antibody } \\
\text { designation }\end{array}$ & Source & $\begin{array}{l}\text { Antigen } \\
\text { specificity }\end{array}$ & $\begin{array}{l}\text { Iso- } \\
\text { type }\end{array}$ & Cellular expression & $\begin{array}{l}\text { Dilution } \\
\text { used }\end{array}$ & Reference \\
\hline MM1A & VMRD & CD3 & $\lg \mathrm{g} 1$ & T cells & $1 / 800$ & Davis et al. 1993 \\
\hline $\mathrm{CH} 138$ & VMRD & unknown & $\lg M$ & Granulocytes & $1 / 400$ & $\begin{array}{l}\text { Naessens et al. 1996; } \\
\text { Keresztes et al. } 1996\end{array}$ \\
\hline HM57 & $\begin{array}{c}\text { Dako } \\
\text { Cytomation }\end{array}$ & CD79á & $\operatorname{lgG} 1$ & B cells & $1 / 100$ & Jones et al. 1993 \\
\hline IL-A29* & $\mid L R I * *$ & $\begin{array}{l}\text { WC1- } \Gamma \delta \text { form } \\
\text { of the T cell } \\
\text { receptor }\end{array}$ & $\operatorname{lgG} 1$ & Gamma/delta T cells & $1 / 25$ & $\begin{array}{l}\text { Morrison and Davis } \\
1991\end{array}$ \\
\hline IL-A21* & ILRI** & $\begin{array}{l}\text { MHC class II } \\
\text { antigen }\end{array}$ & $\operatorname{lgG} 2 a$ & $\begin{array}{c}\text { Macrophages, } \\
\text { dendritic cells, B cells, } \\
\text { activated T cells }\end{array}$ & $1 / 200$ & Taylor et al. 1993 \\
\hline IL-A111* & ILRI** & CD25 & $\lg \mathrm{lg} 1$ & $\begin{array}{c}\text { Activated cells } \\
\text { (IL2-R-bearing cells) }\end{array}$ & $1 / 25$ & Collins et al. 1998 \\
\hline
\end{tabular}

* Monoclonal antibodies from tissue culture supernatant

** International Livestock Research Institute, Nairobi, Kenya

microscopic fields (40x objective). The vision field was placed so that half of the fields covered the tip and the other half the base of the villi as described previously (Sühwold et al. 2010). The pattern of staining by MHC class II antigen-specific antibody did not allow us to count individual cells as reliably as other cell types because not all cells were well defined and there was some overlapping of cells. However, they were subjectively estimated by assessing their numbers and the size of the area occupied.

\section{RNA isolation and $q P C R$}

Samples were removed from $-80{ }^{\circ} \mathrm{C}$ onto a metal block that had also been stored at $-80^{\circ} \mathrm{C}$. Working on the metal block, approximately $100 \mu \mathrm{g}$ of tissue was removed from the sample with a scalpel blade into 2-ml tubes containing $1.5 \mathrm{ml}$ TRIzol ${ }^{\circledR}$ reagent (Invitrogen) and five glass beads. The samples were homogenised in a bead beater for $2 \mathrm{~min}$ and then placed on ice for $10 \mathrm{~min}$. Samples were spun at $12,000 \mathrm{~g}$ for $15 \mathrm{~min}$ at $4{ }^{\circ} \mathrm{C}$ to pellet the solid material, and the supernatant was removed to a new tube. Total RNA extraction was then performed according to the manufacturer's instructions for TRIzol $^{\circledR}$ reagent (Invitrogen). The RNA pellet was resuspended in $100 \mu \mathrm{l}$ of $\mathrm{H}_{2} \mathrm{O}$ and treated with $1.5 \mu \mathrm{l}$ Turbo DNase (Ambion) according to the manufacturer's instructions. The RNA was re-extracted using a standard phenol-chloroform extraction and further purified with RNeasy Mini columns (Qiagen) according to the manufacturer's instructions. Total RNA was eluted from the spin column in $60 \mu \mathrm{l}$ $\mathrm{H}_{2} \mathrm{O}$ and stored at $-80^{\circ} \mathrm{C}$ until required.

cDNA was prepared using $2 \mu \mathrm{g}$ total RNA. OligoDT primers (Invitrogen) were used to prime the complimentary strand and a Supercript III enzyme (Invitrogen) was used to generate the cDNA. qPCR was performed in a total volume of $12 \mu \mathrm{l}$ containing $1.5 \mu \mathrm{l}$ cDNA, $5.8 \mu \mathrm{l}$ SensiMix ${ }^{\mathrm{TM}}$ plus SYBR mastermix (Quantace), $2.7 \mu \mathrm{l} \mathrm{H}_{2} \mathrm{O}$ plus forward and reverse primers. Quantitative PCR was performed on a Rotorgene-6000 (Corbett) and each gene for each biological sample was performed in triplicate. Negative template controls for each primer pair were included on each run. For each biological sample, the mean of the cycle threshold $\left(\mathrm{C}_{\mathrm{T}}\right)$ values for each gene were calculated and normalised against two internal controls; glyceraldehyde-3-phosphate dehydrogenase (GAPDH) and acidic ribosomal protein large, P0 (RPLP0), using the QGene software 
available at http://www.qgene.org/. Mean normalised expression values were employed for statistical analysis.

\section{Data analysis}

Oocyst counts: Arithmetic mean oocyst counts for each treatment group were calculated for each day that oocyst counts were measured. Geometric means of the (oocyst count +1 ) were also calculated. For regression analysis, the highest oocyst count on any day for each individual calf was determined $\left(\mathrm{OC}_{\max }\right)$. $\mathrm{OC}_{\max }$ data were checked for Normal distribution using Anderson-Darling test and were found to diverge significantly. Data were subsequently $\log _{10}$ transformed, which resulted in a distribution more suited to parametric statistics. Arithmetic mean oocyst counts and standard error of the means are presented in graphical form for convenience.

A categorical variable Resistance was derived from the within treatment group ranking according to $\mathrm{OC}_{\max }$. The four animals with the highest oocyst counts in each treatment group were considered to be low-resistance animals. It should be noted, however, that variation in oocyst count among calves within treatment groups might also be attributed to variation in the infective doses used (see Tab. 1). The percentage species composition ( $E$. bovis, $E$. zuernii, other) of the oocyst counts on any one day were estimated using control and treatment group results combined. Efficacy was calculated separately using arithmetic and geometric means. Percentage efficacy with respect to oocyst reduction was calculated to be:

\section{Group mean (untreated calves) at day $x$ - Group mean (treated calves) at day $x$ \\ Group mean untreated calves at day $\mathbf{x}$ \\ x 100}

Liveweight: The change in liveweight between day +14 (treatment day) and day +24 (end of trial) was calculated for each calf. This variable was found to be non-normally distributed using the Anderson-Darling test. However, when expressed as a percentage of the day +14 weight, the day +24 weight was normally distributed and suited to parametric analysis without transformation. Twotailed t-tests were subsequently used to assess the effect of treatment with statistical significance taken as $\mathrm{p}<0.05$.

\section{Histology, immunohistochemistry and gene} expression: Samples were processed for three animals from each treatment group. For each sample, 12 high powered fields (hpf) were observed and the specific cell types were manually counted to provide a mean number of cells/hpf. All cell types were found to fit a Normal distribution, but several of the mean normalised gene expression values required $\log _{10}$ transformation (Il-2, CD14, TNF- $\alpha$ ) for parametric analysis. Two-tailed t-tests were subsequent ly used to assess the effect of treatment and of resistance category with statistical significance taken as $\mathrm{p}<0.05$.

\section{Results}

\section{Efficacy}

Efficacy was assessed using treatment group arithmetic and geometric means of faecal oocyst counts for each day after treatment with the test product. Results are shown in Tab. 3. Using the arithmetic mean, efficacy was $77.8 \%$ two days after treatment, increasing to $99.2 \%$ three days after treatment and $100 \%$ within 5 days, where it remained until 7 days after treatment.

\section{Oocyst counts}

Arithmetic mean faecal oocyst counts for each treatment group are shown in Fig. 1. Oocysts were first detected in faeces of two calves on day +10 and 12 of 16 calves were shedding oocysts by day +14 . Faecal oocyst counts were not significantly affected by treatment until trial day +17 (3 days post treatment). However, they remained significantly different thereafter until termination of the trial. The percentage of each species is shown in Fig. 2. 
Tab. 3 Efficacy of toltrazuril treatment based on geometric and arithmetic means of faecal oocyst counts

\begin{tabular}{|c|c|c|}
\hline \multirow{2}{*}{ Days after treatment $($ day +14$)$} & \multicolumn{2}{|c|}{ Efficacy (\%) } \\
\hline & Using arithmetic mean & Using geometric mean \\
\hline 0 (day +14) & 53.7 & -161.1 \\
\hline 1 (day +15) & -103 & 29.8 \\
\hline 2 (day +16) & 77.8 & 80.77 \\
\hline 3 (day +17) & 99.2 & 99.6 \\
\hline 4 (day +18 ) & 99.7 & 99.6 \\
\hline 5 (day +19) & 100 & 100 \\
\hline 6 (day +20 ) & 100 & 100 \\
\hline 7 (day +21) & 100 & 100 \\
\hline 8 (day +22 ) & 99.7 & 100 \\
\hline 9 (day +23$)$ & 86.6 & 98.5 \\
\hline 10 (day +24) & 97.9 & 99.3 \\
\hline
\end{tabular}

\section{Liveweights}

Mean total liveweight gain from day +2 to day +24 was $14.5 \pm 1.9$ (SD) $\mathrm{kg}$ in the toltrazuril-treated group and $12.8 \pm 3.9$ (SD) $\mathrm{kg}$ in the control group. This was not a significant difference $(p=0.28)$. When measured between treatment day $($ day +14$)$ and trial termination on day +24 , mean liveweight gain was $4.6 \pm 1.1$ (SD) $\mathrm{kg}$ in the toltrazuril-treated group and $2.9 \pm 3.7$ (SD) $\mathrm{kg}$ in the control group. Again, this was not a significant difference $(p=0.24)$.

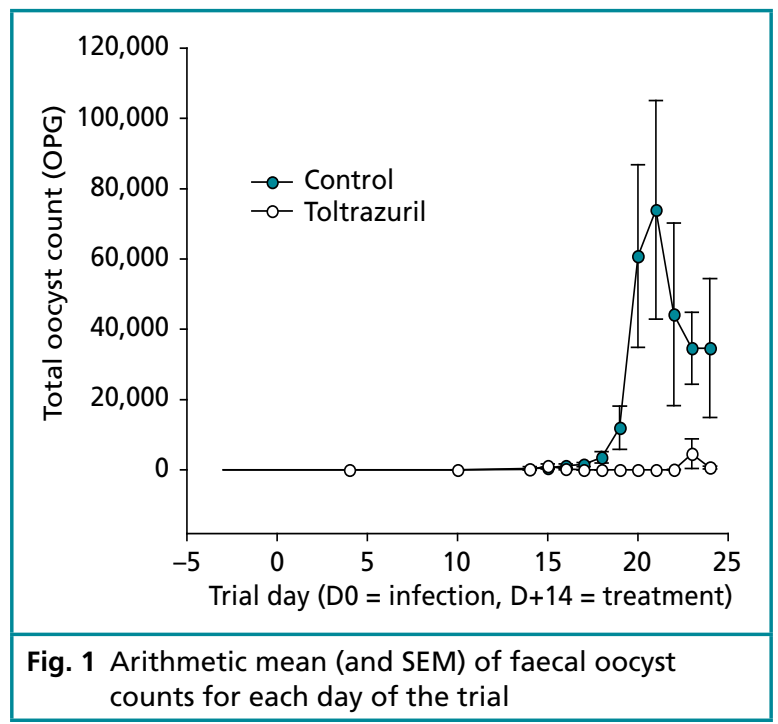

\section{Faecal consistency scores}

Mean (and SEM) of faecal consistency scores are shown in Fig. 3. Faecal consistency scores increased from 1 in both groups after infection at day 0 to peak on day +18 (treatment $+4 \mathrm{~d}$ ) at 2.6 in the control group and 2.0 in the treated group. They were statistically similar $(p>0.05)$ until day +19 , when the toltrazuril-treated group began to decline (1.9 on day 19, compared with 3.0 in the control group, $\mathrm{p}<0.001)$ ). After this point, the two

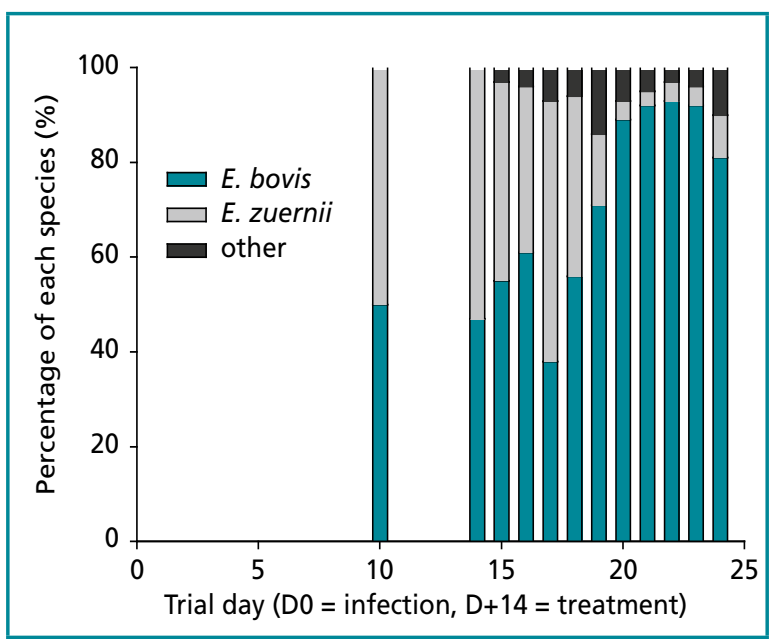

Fig. 2 Percentage of all oocysts of E. bovis, E. zuernii or other during the trial period 
Tab. 4 Summary of observations taken over the entire study by calf and treatment group

\begin{tabular}{|c|c|c|c|c|c|c|c|c|}
\hline Calf ID & Group & $\Delta \mathbf{W}$ & $\mathbf{O C}_{\max }$ & $O C_{\text {mean }}$ & $\mathrm{FS}_{\max }$ & $\mathrm{FS}_{\text {mean }}$ & $\begin{array}{l}\text { Colon } \\
\text { Erosion }\end{array}$ & $\begin{array}{l}\text { Colon } \\
\text { Nodule }\end{array}$ \\
\hline 3 & Control & 4.9 & 81,000 & 1,4171 & 4 & 2.1 & 0 & 1 \\
\hline 6 & Control & -4.6 & 48,600 & 10,679 & 4 & 2.2 & 0 & 1 \\
\hline 7 & Control & 4 & 150,000 & 21,607 & 4 & 1.8 & 0 & 1 \\
\hline 10 & Control & 5.8 & 98,000 & 17,064 & 3 & 1.7 & 0 & 0 \\
\hline 14 & Control & 2.2 & 14,400 & 2,671 & 4 & 1.7 & 1 & 1 \\
\hline 16 & Control & 6 & 51,700 & 5,950 & 3 & 1.8 & 1 & 0 \\
\hline 18 & Control & 5.5 & 79,600 & 15,743 & 3 & 1.9 & 0 & 0 \\
\hline 21 & Control & -0.4 & 275,200 & 65,250 & 4 & 2.0 & 1 & 1 \\
\hline 4 & Toltrazuril & 5.2 & 100 & 14 & 3 & 1.4 & 0 & 0 \\
\hline 5 & Toltrazuril & 7.2 & 2,300 & 236 & 2 & 1.3 & 0 & 0 \\
\hline 8 & Toltrazuril & 4.4 & 34,200 & 2,457 & 3 & 1.8 & 0 & 0 \\
\hline 11 & Toltrazuril & 4.1 & 600 & 57 & 3 & 1.4 & 0 & 0 \\
\hline 13 & Toltrazuril & 4.4 & 1,900 & 264 & 3 & 1.1 & 0 & 0 \\
\hline 17 & Toltrazuril & 4 & 5,400 & 550 & 2 & 1.3 & 0 & 0 \\
\hline 19 & Toltrazuril & 3.8 & 1,400 & 150 & 2 & 1.1 & 0 & 0 \\
\hline 22 & Toltrazuril & 4 & 2,400 & 386 & 4 & 1.2 & 0 & 0 \\
\hline
\end{tabular}

$\Delta \mathrm{W}$, change in weight from day 14 to day $24 ; O C_{\max }$ maximum oocyst count detected during study period;

$\mathrm{OC}_{\text {mean }}$, arithmetic mean oocyst count for study period; $\mathrm{FS}_{\text {max }^{\prime}}$ maximum faecal score obtained during the study period;

$\mathrm{FS}_{\text {mean' }}$ arithmetic mean faecal score for study period

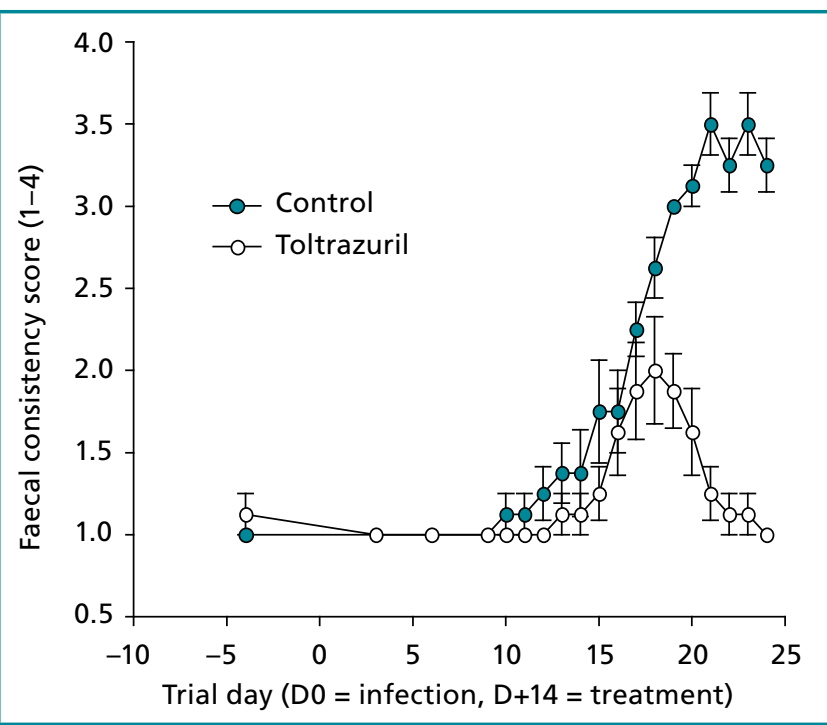

Fig. 3 Mean (and SEM) of faecal consistency score throughout the trial. Scoring system: 1 = normal to pasty; 2 = semiliquid to liquid; 3 = watery; haemorrhagic and/or with tissue groups remained significantly different, the treatment group returning to a mean score of 1.0 by day +24 and the control group reaching a mean of 3.5 on day +21 and day +23 . In the control group, four calves had faecal consistency scores of 4 (i.e. haemorrhagic faeces or containing tissue) on day +21 and day +23 and no calf had a score of less than 3 (watery) after day +19 . In contrast, in the toltrazuril-treated group, no calf exceeded a score of 3 at any time and only one calf had a score of 3 beyond day +18 .

\section{Post-mortem gross pathology findings}

The most severe pathology was seen in the colon. Presence or absence of nodular change in the colon or mucosal erosion are summarised in Tab. 4 and examples of the pathology 
Tab. 5 Cell counts per high power field (mean value from 10 fields per animal) and cytokine gene expression from the ILEUM of 12 calves. Sample numbers: cell counts: 3 treatment and 3 control; 3 high resistance and 3 low resistance; cytokine gene expression: 8 treatment and 8 control; 8 high resistance and 8 low resistance samples

\begin{tabular}{|c|c|c|c|c|c|c|}
\hline & \multicolumn{2}{|c|}{ Toltrazuril treatment } & \multirow[b]{3}{*}{$p(\%)$} & \multicolumn{2}{|c|}{ Resistance classification } & \multirow[b]{3}{*}{$\mathrm{p}(\%)$} \\
\hline & Treatment & Control & & High & Low & \\
\hline Variable & $\begin{array}{c}\mu, \text { Med. } \\
\text { (Min-Max) }\end{array}$ & $\begin{array}{c}\mu, \text { Med. } \\
\text { (Min-Max) }\end{array}$ & & $\begin{array}{c}\mu, \text { Med. } \\
\text { (Min-Max) }\end{array}$ & $\begin{array}{c}\mu, \text { Med. } \\
\text { (Min-Max) }\end{array}$ & \\
\hline \multicolumn{7}{|c|}{ Cell counts per hpf } \\
\hline Eosinophils & $\begin{array}{c}25.50,29.30 \\
(15.30-31.90)\end{array}$ & $\begin{array}{c}26.77,26.40 \\
(21.30-32.60)\end{array}$ & $0.846^{a}$ & $\begin{array}{c}31.27,31.90 \\
(29.30-32.60)\end{array}$ & $\begin{array}{c}21.00,21.30 \\
(15.30-26.40)\end{array}$ & $0.038^{a}$ \\
\hline $\begin{array}{c}\mathrm{CH} 138 \\
\text { Granulocytes }\end{array}$ & $\begin{array}{c}7.33,7.00 \\
(6.70-8.30)\end{array}$ & $\begin{array}{c}4.80,4.40 \\
(1.70-8.30)\end{array}$ & $0.269^{a}$ & $\begin{array}{c}7.77,8.30 \\
(6.70-8.30)\end{array}$ & $\begin{array}{c}4.37,4.40 \\
(1.70-7.00)\end{array}$ & $0.104^{a}$ \\
\hline $\begin{array}{c}\text { CD3 } \\
\text { Lymphocytes }\end{array}$ & $\begin{array}{l}82.97,84.90 \\
(76.1-87.90)\end{array}$ & $\begin{array}{c}99.2,108.6 \\
(64.9-124.0)\end{array}$ & $0.420^{\mathrm{a}}$ & $\begin{array}{c}90.87,87.90 \\
(76.10-108.60)\end{array}$ & $\begin{array}{c}91.3,84.9 \\
(64.9-124.0)\end{array}$ & $0.985^{a}$ \\
\hline $\begin{array}{c}\text { WC1 } \\
\gamma \delta \text { T cells }\end{array}$ & $\begin{array}{c}8.10,8.60 \\
(5.80-9.90)\end{array}$ & $\begin{array}{c}11.43,11.50 \\
(8.20-14.60)\end{array}$ & $0.206^{\mathrm{a}}$ & $\begin{array}{c}8.63,8.60 \\
(5.80-11.50)\end{array}$ & $\begin{array}{c}10.90 .9 .90 \\
(8.20-14.60)\end{array}$ & $0.420^{\mathrm{a}}$ \\
\hline $\begin{array}{c}\text { CD25 } \\
\text { IL-2r-bearing }\end{array}$ & $\begin{array}{c}12.83,9.30 \\
(9.20-20.00)\end{array}$ & $\begin{array}{c}15.07,15.10 \\
(8.90-21.20)\end{array}$ & $0.681^{\mathrm{a}}$ & $\begin{array}{l}14.80,15.10 \\
(9.30-20.00)\end{array}$ & $\begin{array}{c}13.10,9.20 \\
(8.90-21.20)\end{array}$ & $0.755^{a}$ \\
\hline MHC II & $\begin{array}{c}107.86,99.78 \\
(98.20-125.60)\end{array}$ & $\begin{array}{c}130.60,121.90 \\
(121.10-148.80)\end{array}$ & $0.148^{\mathrm{a}}$ & $\begin{array}{c}114.97,121.10 \\
(98.20-125.60)\end{array}$ & $\begin{array}{l}123.50,121.9 \\
(99.8-148.8)\end{array}$ & $0.633^{\mathrm{a}}$ \\
\hline \multicolumn{7}{|c|}{ Cytokine gene expression } \\
\hline IL-1 $\beta$ & $\begin{array}{c}1.4 \mathrm{E}-4,1.0-4 \\
(6.1 \mathrm{E}-5-3.3 \mathrm{E}-4)\end{array}$ & $\begin{array}{c}1.2 \mathrm{E}-4,9.4 \mathrm{E}-5 \\
(1.9 \mathrm{E}-5-2.7 \mathrm{E}-4)\end{array}$ & $0.744^{\mathrm{a}}$ & $\begin{array}{c}1.0 \mathrm{E}-4,9.6 \mathrm{E}-5 \\
(3.9 \mathrm{E}-5-1.9 \mathrm{E}-4)\end{array}$ & $\begin{array}{c}1.5 \mathrm{E}-4,1.1 \mathrm{E}-4 \\
(1.9 \mathrm{E}-5-3.3 \mathrm{E}-4)\end{array}$ & $0.345^{\mathrm{a}}$ \\
\hline IL-2 & $\begin{array}{l}1.8 \mathrm{E}-4,1.0 \mathrm{E}-4 \\
(6 \mathrm{E}-6-1.3 \mathrm{E}-3)\end{array}$ & $\begin{array}{c}2.2 \mathrm{E}-5,2.2 \mathrm{E}-5 \\
(1.2 \mathrm{E}-5-2.9 \mathrm{E}-5)\end{array}$ & $<0.001^{b}$ & $\begin{array}{l}1.9 \mathrm{E}-4,1.5 \mathrm{E}-5 \\
(7 \mathrm{E}-6-1.4 \mathrm{E}-3)\end{array}$ & $\begin{array}{l}1.7 \mathrm{E}-5,1.8 \mathrm{E}-5 \\
(6 \mathrm{E}-6-2.9 \mathrm{E}-5)\end{array}$ & $0.646^{\mathrm{b}}$ \\
\hline IL-8 & 0.00 & 0.00 & & 0.00 & 0.00 & \\
\hline IL-10 & $\begin{array}{c}1.2 \mathrm{E}-3,1.1 \mathrm{E}-3 \\
(8.8 \mathrm{E}-4-1.5 \mathrm{E}-3)\end{array}$ & $\begin{array}{c}\text { 7.9E-4, 7.7E-4 } \\
(3.6 \mathrm{E}-4-1.2 \mathrm{E}-3)\end{array}$ & $0.021^{\mathrm{a}}$ & $\begin{array}{c}9.5 \mathrm{E}-4,9.1 \mathrm{E}-4 \\
(6.2 \mathrm{E}-4-1.4 \mathrm{E}-3)\end{array}$ & $\begin{array}{c}9.9 \mathrm{E}-4,1.1 \mathrm{E}-3 \\
(3.6 \mathrm{E}-4-1.4 \mathrm{E}-3)\end{array}$ & $0.824^{a}$ \\
\hline $\mathrm{CD} 14$ & $\begin{array}{c}2.9 \mathrm{E}-3,3.2 \mathrm{E}-3 \\
(0.0-7.8 \mathrm{E}-3)\end{array}$ & $\begin{array}{l}1.9 \mathrm{E}-3,1.6 \mathrm{E}-3 \\
(0.0-4.2 \mathrm{E}-3)\end{array}$ & $0.430^{b}$ & $\begin{array}{l}2.4 \mathrm{E}-3,1.6 \mathrm{E}-3 \\
(0.00-7.8 \mathrm{E}-3)\end{array}$ & $\begin{array}{c}2.4 \mathrm{E}-3,3.3 \mathrm{E}-3 \\
(0.0-4.8 \mathrm{E}-3)\end{array}$ & $0.959^{b}$ \\
\hline IFN- $\gamma$ & $\begin{array}{c}2.3 \mathrm{E}-4,2.2 \mathrm{E}-4 \\
(1.1 \mathrm{E}-4-4.4 \mathrm{E}-4)\end{array}$ & $\begin{array}{l}3.0 \mathrm{E}-4,3.3 \mathrm{E}-4 \\
(0.00-4.7 \mathrm{E}-4)\end{array}$ & $0.336^{\mathrm{a}}$ & $\begin{array}{l}2.3 E-4,2.2 E-4 \\
(0.00-4.4 E-4)\end{array}$ & $\begin{array}{c}2.9 \mathrm{E}-4,3.2 \mathrm{E}-4 \\
(1.2 \mathrm{E}-4-4.8 \mathrm{E}-4)\end{array}$ & $0.428^{a}$ \\
\hline TNF- $\alpha$ & $\begin{array}{l}3.3 \mathrm{E}-4,4.3 \mathrm{E}-4 \\
(0.00-8.8 \mathrm{E}-4)\end{array}$ & $\begin{array}{l}2.7 \mathrm{E}-4,2.1 \mathrm{E}-4 \\
(0.00-6.7 \mathrm{E}-4)\end{array}$ & $0.73^{b}$ & $\begin{array}{l}2.8 E-4,2.3 E-4 \\
(0.00-6.7 E-4)\end{array}$ & $\begin{array}{l}3.1 \mathrm{E}-4,3.0 \mathrm{E}-4 \\
(0.00-8.8 \mathrm{E}-4)\end{array}$ & $0.832^{\mathrm{b}}$ \\
\hline IP-10 & $\begin{array}{c}7.9 \mathrm{E}-3,5.3 \mathrm{E}-3 \\
(2.1 \mathrm{E}-3-2.5 \mathrm{E}-2)\end{array}$ & $\begin{array}{c}1.5 \mathrm{E}-2,1.4 \mathrm{E}-2 \\
(4.0 \mathrm{E}-3-3.3 \mathrm{E}-2)\end{array}$ & $0.082^{\mathrm{a}}$ & $\begin{array}{c}1.3 \mathrm{E}-2,9.5 \mathrm{E}-3 \\
(3.7 \mathrm{E}-3-3.3 \mathrm{E}-2)\end{array}$ & $\begin{array}{c}1.0 \mathrm{E}-2,9.8 \mathrm{E}-3 \\
(2.1 \mathrm{E}-3-2.5 \mathrm{E}-2)\end{array}$ & $0.596^{\mathrm{a}}$ \\
\hline
\end{tabular}

a t-test on untransformed data; ${ }^{b}$ t-test on log-transformed data; ${ }^{c}$ binary logistic regression of categorical variables 
Tab. 6 Cell counts per high power field (mean value from 10 fields per animal) and cytokine gene expression from the COLON of 12 calves. Sample numbers: cell counts per high power field: 3 treatment and 3 control; 3 high resistance and 3 low resistance; cytokine gene expression: 8 treatment and 8 control; 8 high resistance and 8 low resistance samples

\begin{tabular}{|c|c|c|c|c|c|c|}
\hline \multirow[b]{3}{*}{ Variable } & \multicolumn{2}{|c|}{ Toltrazuril treatment } & \multirow[b]{3}{*}{ p (\%) } & \multicolumn{2}{|c|}{ Resistance classification } & \multirow[b]{3}{*}{$\mathrm{p}(\%)$} \\
\hline & Treatment & Control & & High & Low & \\
\hline & $\begin{array}{c}\mu, \text { Med. } \\
\text { (Min-Max) }\end{array}$ & $\begin{array}{c}\mu, \text { Med. } \\
\text { (Min-Max) }\end{array}$ & & $\begin{array}{c}\mu, \text { Med. } \\
\text { (Min-Max) }\end{array}$ & $\begin{array}{c}\mu, \text { Med. } \\
\text { (Min-Max) }\end{array}$ & \\
\hline \multicolumn{7}{|c|}{ Cell counts per hpf } \\
\hline Eosinophils & $\begin{array}{c}14.83,16.60 \\
(9.30-18.60)\end{array}$ & $\begin{array}{c}18.00,20.40 \\
(12.00-21.60)\end{array}$ & $0.487^{a}$ & $\begin{array}{c}20.20,20.40 \\
(29.30-21.60)\end{array}$ & $\begin{array}{c}12.63,12.00 \\
(9.30-16.60)\end{array}$ & $0.030^{\mathrm{a}}$ \\
\hline $\begin{array}{c}\mathrm{CH} 138 \\
\text { Granulocytes }\end{array}$ & $\begin{array}{c}2.40,1.20 \\
(0.70-5.30)\end{array}$ & $\begin{array}{c}5.57,4.60 \\
(1.80-10.30)\end{array}$ & $0.335^{a}$ & $\begin{array}{c}2.53,1.80 \\
(1.20-4.60)\end{array}$ & $\begin{array}{c}5.43,5.30 \\
(0.70-10.30)\end{array}$ & $0.383^{\mathrm{a}}$ \\
\hline $\begin{array}{c}\text { CD3 } \\
\text { Lymphocytes }\end{array}$ & $\begin{array}{c}18.07,17.96 \\
(17.59-18.67)\end{array}$ & $\begin{array}{c}15.64,19.49 \\
(7.16-20.27)\end{array}$ & $0.598^{\mathrm{a}}$ & $\begin{array}{c}19.11,19.49 \\
(17.59-108.60)\end{array}$ & $\begin{array}{c}14.60,17.96 \\
(7.16-18.67)\end{array}$ & $0.301^{a}$ \\
\hline $\begin{array}{c}\text { WC1 } \\
\gamma \delta \text { T cells }\end{array}$ & $\begin{array}{c}3.40,3.30 \\
(2.30-4.60)\end{array}$ & $\begin{array}{c}5.73,3.50 \\
(2.10-11.60)\end{array}$ & $0.485^{a}$ & $\begin{array}{c}6.57,4.60 \\
(3.50-11.60)\end{array}$ & $\begin{array}{c}2.57,2.30 \\
(2.10-3.30)\end{array}$ & $0.194^{a}$ \\
\hline $\begin{array}{c}\text { CD25 } \\
\text { IL-2r-bearing }\end{array}$ & $\begin{array}{c}11.36,10.78 \\
(9.40-13.90)\end{array}$ & $\begin{array}{c}9.17,9.40 \\
(3.00-15.11)\end{array}$ & $0.590^{\mathrm{a}}$ & $\begin{array}{c}11.76,10.78 \\
(9.40-15.11)\end{array}$ & $\begin{array}{c}8.77,9.40 \\
(3.00-13.90)\end{array}$ & $0.452^{\mathrm{a}}$ \\
\hline MHC II & $\begin{array}{c}17.31,18.43 \\
(15.48-18.43)\end{array}$ & $\begin{array}{c}18.37,17.20 \\
(5.92-32.00)\end{array}$ & $0.896^{a}$ & $\begin{array}{c}18.78,18.43 \\
(5.92-32.00)\end{array}$ & $\begin{array}{c}16.90,17.20 \\
(15.48-18.03)\end{array}$ & $0.816^{a}$ \\
\hline \multicolumn{7}{|c|}{ Cytokine gene expression } \\
\hline IL-1 $\beta$ & $\begin{array}{l}3.3 \mathrm{E}-4,2.5 \mathrm{E}-4 \\
(0.00-1.1 \mathrm{E}-3)\end{array}$ & $\begin{array}{c}3.3 \mathrm{E}-4,2.8 \mathrm{E}-4 \\
(3.6 \mathrm{E}-5-8.9 \mathrm{E}-4)\end{array}$ & $0.990^{\mathrm{a}}$ & $\begin{array}{l}3.5 \mathrm{E}-4,2.8 \mathrm{E}-4 \\
(0.00-8.9 \mathrm{E}-4)\end{array}$ & $\begin{array}{c}3.0 \mathrm{E}-4,2.0 \mathrm{E}-4 \\
(2.7 \mathrm{E}-5-1.1 \mathrm{E}-3)\end{array}$ & $0.780^{\mathrm{a}}$ \\
\hline IL-2 & $\begin{array}{c}4.4 \mathrm{E}-5,2.0 \mathrm{E}-5 \\
(9.0 \mathrm{E}-6-1.7 \mathrm{E}-4)\end{array}$ & $\begin{array}{c}1.9 \mathrm{E}-5,2.1 \mathrm{E}-5 \\
(2.0 \mathrm{E}-6-2.8 \mathrm{E}-5)\end{array}$ & $0.385^{b}$ & $\begin{array}{c}3.7 \mathrm{E}-5,1.9 \mathrm{E}-5 \\
(9.0 \mathrm{E}-6-1.7 \mathrm{E}-4)\end{array}$ & $\begin{array}{c}2.6 \mathrm{E}-5,2.4 \mathrm{E}-5 \\
(2.0 \mathrm{E}-6-5.6 \mathrm{E}-5)\end{array}$ & $0.276^{\mathrm{b}}$ \\
\hline IL-8 & 0.00 & 0.00 & & 0.00 & 0.00 & \\
\hline IL-10 & $\begin{array}{l}3.0 \mathrm{E}-4,3.1 \mathrm{E}-4 \\
(0.00-6.3 \mathrm{E}-4)\end{array}$ & $\begin{array}{l}2.7 \mathrm{E}-4,2.0 \mathrm{E}-4 \\
(0.00-9.0 \mathrm{E}-4)\end{array}$ & $0.819^{a}$ & $\begin{array}{l}2.4 \mathrm{E}-4,2.0 \mathrm{E}-4 \\
(0.00-4.3 \mathrm{E}-4)\end{array}$ & $\begin{array}{l}3.3 \mathrm{E}-4,2.6 \mathrm{E}-4 \\
(0.00-9.0 \mathrm{E}-4)\end{array}$ & $0.438^{a}$ \\
\hline CD14 & $\begin{array}{c}4.9 \mathrm{E}-3,4.6 \mathrm{E}-3 \\
(1.5 \mathrm{E}-4-9.6 \mathrm{E}-3)\end{array}$ & $\begin{array}{l}1.8 \mathrm{E}-3,1.6 \mathrm{E}-3 \\
(0.00-3.9 \mathrm{E}-3)\end{array}$ & $0.430^{\mathrm{b}}$ & $\begin{array}{l}3.3 E-3,3.6 E-3 \\
(0.00-7.6 E-3)\end{array}$ & $\begin{array}{l}3.4 \mathrm{E}-3,3.4 \mathrm{E}-3 \\
(0.00-9.6 \mathrm{E}-3)\end{array}$ & $0.954^{b}$ \\
\hline IFN- $\gamma$ & $\begin{array}{l}9.9 \mathrm{E}-4,8.6 \mathrm{E}-4 \\
(0.00-2.2 \mathrm{E}-3)\end{array}$ & $\begin{array}{c}9.0 \mathrm{E}-4,8.8 \mathrm{E}-4 \\
(2.1 \mathrm{E}-4-2.0 \mathrm{E}-3)\end{array}$ & $0.802^{\mathrm{a}}$ & $\begin{array}{l}9.2 \mathrm{E}-4,9.2 \mathrm{E}-4 \\
(0.00-2.1 \mathrm{E}-3)\end{array}$ & $\begin{array}{c}9.7 \mathrm{E}-4,8.1 \mathrm{E}-4 \\
(2.1 \mathrm{E}-4-2.2 \mathrm{E}-3)\end{array}$ & $0.876^{a}$ \\
\hline TNF- $\alpha$ & $\begin{array}{l}4.8 \mathrm{E}-4,5.2 \mathrm{E}-4 \\
(0.00-8.2 \mathrm{E}-4)\end{array}$ & $\begin{array}{l}1.8 \mathrm{E}-4,4.6 \mathrm{E}-5 \\
(0.00-5.6 \mathrm{E}-4)\end{array}$ & $0.037^{b}$ & $\begin{array}{l}3.1 \mathrm{E}-4,2.3 \mathrm{E}-4 \\
(0.00-8.2 \mathrm{E}-4)\end{array}$ & $\begin{array}{l}3.5 \mathrm{E}-4,3.8 \mathrm{E}-4 \\
(0.00-7.6 \mathrm{E}-4)\end{array}$ & $0.801^{b}$ \\
\hline IP-10 & $\begin{array}{l}3.8 \mathrm{E}-2,2.8 \mathrm{E}-2 \\
(0.00-9.7 \mathrm{E}-2)\end{array}$ & $\begin{array}{c}3.1 \mathrm{E}-2,2.8 \mathrm{E}-2 \\
(1.2 \mathrm{E}-2-7.3 \mathrm{E}-2)\end{array}$ & $0.595^{a}$ & $\begin{array}{l}4.2 \mathrm{E}-2,2.9 \mathrm{E}-2 \\
(0.00-9.7 \mathrm{E}-2)\end{array}$ & $\begin{array}{c}2.6 \mathrm{E}-2,2.8 \mathrm{E}-2 \\
(7.9 \mathrm{E}-3-5.1 \mathrm{E}-2)\end{array}$ & $0.209^{a}$ \\
\hline
\end{tabular}

a $\mathrm{t}$-test on untransformed data; ${ }^{\mathrm{b}} \mathrm{t}$-test on log-transformed data; ${ }^{\mathrm{c}}$ binary logistic regression of categorical variables 

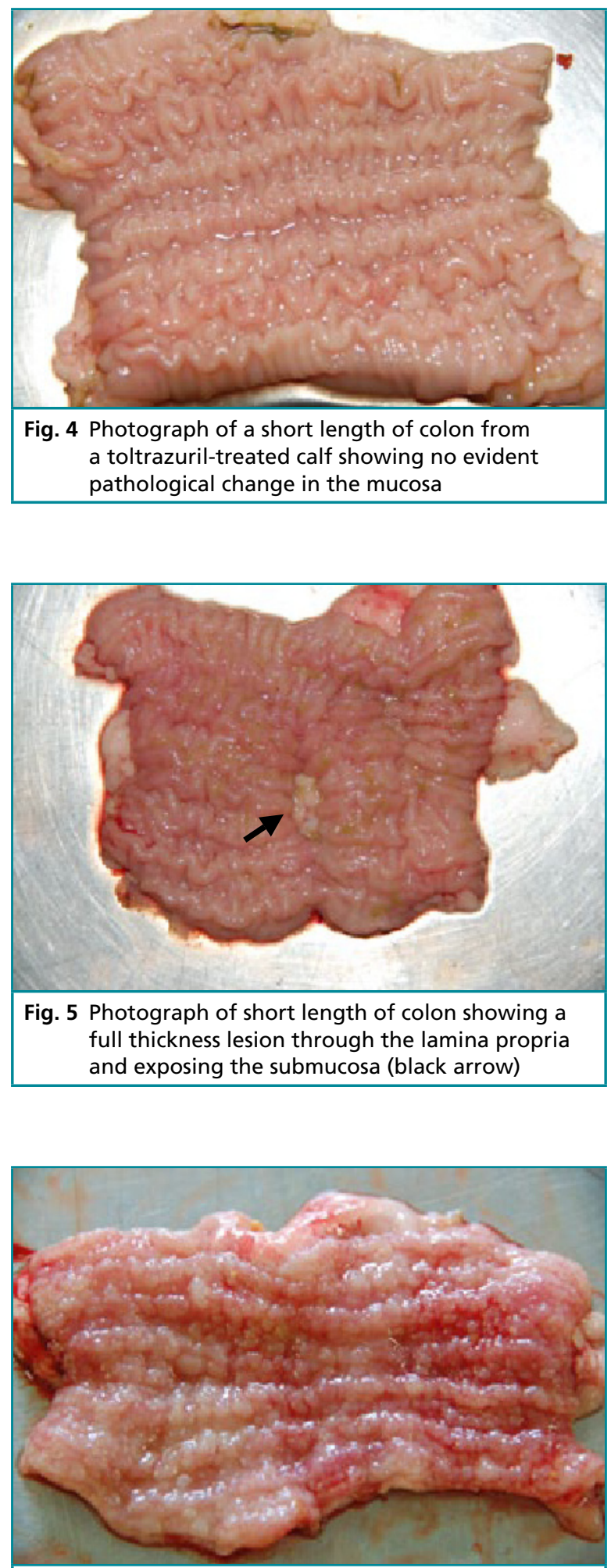

Fig. 6 Photograph of short length of colon from a control calf showing extensive, generalised nodularity of the mucosa with haemorrhagic change are shown in Figs. 4-6. Toltrazuril-treated calves did not show any evidence of pathological change in the colon and ileum. Among the control calves, the most common lesions were nodular change and erosions in the colon. Two calves had full thickness lesions of 5 to $10 \mathrm{~mm}$ diameter completely through the lamina propria and exposing the underlying connective tissue (Fig. 5). One calf had more superficial erosions of the mucosa, also of about $5 \mathrm{~mm}$ diameter. Five calves showed nodular change in the colonic mucosa (example seen in Fig. 6). Three calves had oedema of the colon and mesocolon. Changes in the ileum were only noted in three animals and consisted mainly of oedema and mild nodular change to the mucosa. These findings are broadly consistent with the clinical presentation of the calves: those with the most severe post-mortem lesions were the same calves that developed faecal consistency scores of 4 at some time in the trial. The three control calves that did not develop score 4 faeces had much more limited post-mortem changes (Tab. 4).

\section{Histology and immunohistochemistry}

Most samples showed extensive granulocyte and mononuclear cell infiltration in the lamina propria. Only a few meronts were seen in the samples examined. Fig. 7 shows a typical meront in the ileum of one control calf. Fig. 8 shows the same Field stained to show CD3+ lymphocytes and MHC II expressing cells. In the samples from the ileum and from the colon there were no significant differences between the toltrazuril and control animals in the cell counts per high-power fields (Tabs. 5 and 6). Fig. 9 shows a representative field stained for CH138+ granulocytes and $\mathrm{WC} 1 \gamma \delta+$ lymphocytes. The count of eosinophils was significantly higher in the animals classified as more highly resistant in the ileum $(p=0.038)$ and in the colon $(p=0.030)$.

\section{Cytokine gene expression}

In the samples from the ileum, two genes were expressed more strongly in the toltrazuril-treated animals: IL-2 $(p<0.001)$ and IL-10 $(p=0.021)$ 


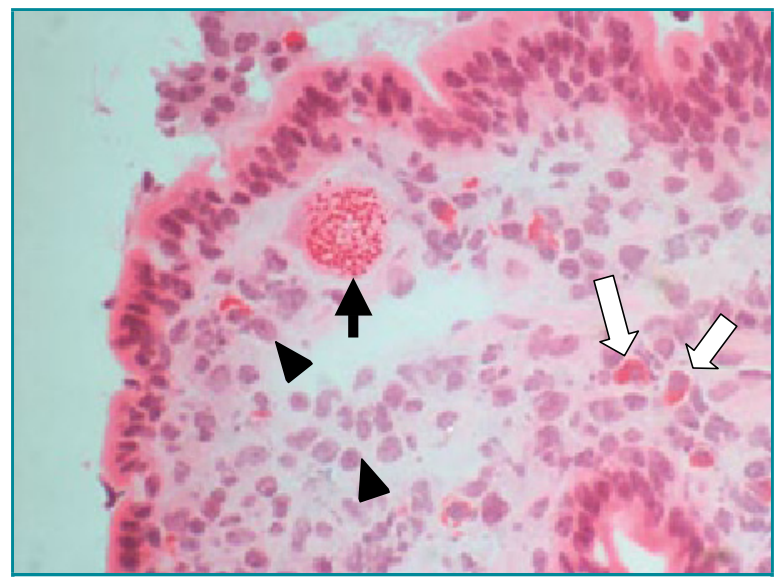

Fig. 7 Complete high-power field from a control calf, stained with $\mathrm{H} \& \mathrm{E}$ showing a single meront (black arrow) and heavy infiltration of the lamina propria with many eosinophils (examples shown by open arrows) and mononuclear inflammatory cells (examples shown by solid arrowheads)

(Tabs. 5 and 6). In the samples from the colon, only TNF- $\alpha$ was differentially expressed, being higher in the toltrazuril-treated calves $(p=0.037)$. IL- 8 was not expressed in any of the samples.

\section{Associations of measured variables with nodular change in the colon}

Nodular change in the colon was significantly associated with measures of weight gain, faecal score and oocyst count (Tab. 7). Colon nodularity

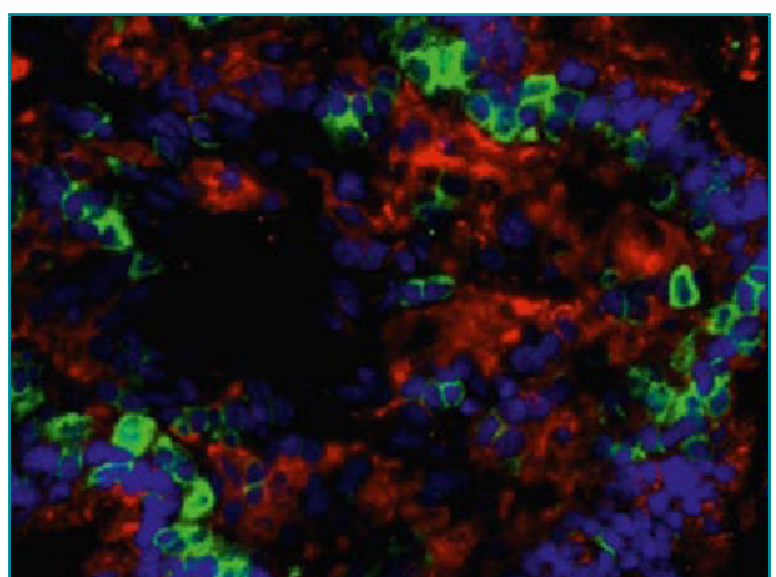

Fig. 8 Complete high-power field from the same control calf as Fig. 7, stained with FITC for CD3+ lymphocytes (green) and with Texas Red for MHC II-expressing cells (red). Cell nuclei are stained with DAPI dilactate (blue) was not significantly associated with any of the cell count or cytokine gene expression variables, although the following tendencies were noted: CH138 (granulocytes) were more numerous in nodular tissue (mean 7.45 vs. 2.35 cells/colon hpf, $\mathrm{p}=$ 0.091); $\log _{10}$ CD14 lower in colonic nodular tissue (median 0.0000 vs. 0.0037 relative gene expression, $\mathrm{p}=0.071) ; \log _{10}$ TNF- $\alpha$ was lower in nodular tissue (median 0.00000 vs. 0.00043 relative gene expression, $\mathrm{p}=0.065)$.

Tab. 7 Parasite burden, weight change, faecal score of animals with and without severe nodular change

\begin{tabular}{|c|c|c|c|}
\hline & Nodular change $(n=5)$ & No nodular change $(n=11)$ & \\
\hline Variable & $\begin{array}{c}\text { Mean, Median } \\
\text { (Minimum-Maximum) }\end{array}$ & $\begin{array}{c}\text { Mean, Median } \\
\text { (Minimum-Maximum) }\end{array}$ & p (\%) \\
\hline$\Delta \mathrm{W}(\%)$ & $\begin{array}{c}102.22,103.72 \\
(89.33-110.45)\end{array}$ & $\begin{array}{c}110.81,111.43 \\
(106.95-116.40)\end{array}$ & $0.008^{a}$ \\
\hline $\mathrm{OC}_{\max }$ & $\begin{array}{c}113,840,81,000 \\
(14,400-275,200)\end{array}$ & $\begin{array}{l}25,236,2,400 \\
(100-98,000)\end{array}$ & $0.013^{b}$ \\
\hline$O C \mu$ & $\begin{array}{c}22,876,14,171 \\
(2,671-65,250)\end{array}$ & $\begin{array}{c}3,897,386 \\
(14-17,064)\end{array}$ & $0.013^{b}$ \\
\hline $\mathrm{FS}_{\max }$ & $\begin{array}{c}4,4 \\
(4-4)\end{array}$ & $\begin{array}{l}2.8,3.0 \\
(2-4)\end{array}$ & $0.002^{c}$ \\
\hline $\mathrm{FS} \mu$ & $\begin{array}{c}1.97,1.95 \\
(1.73-2.22)\end{array}$ & $\begin{array}{c}1.45,1.36 \\
(1.14-1.86)\end{array}$ & $0.003^{a}$ \\
\hline
\end{tabular}

a t-test on untransformed data; ${ }^{b}$ t-test on log-transformed data; ${ }^{c}$ binary logistic regression of categorical variables 


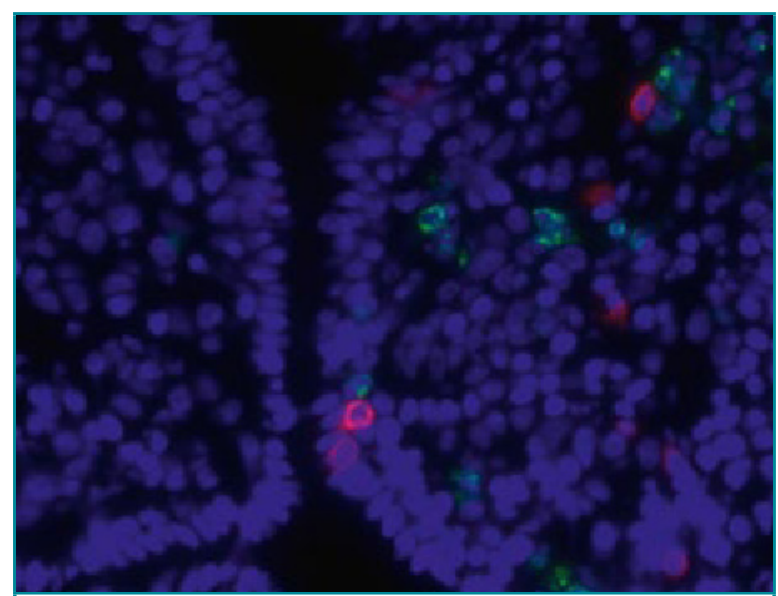

Fig. 9 Complete high-power field from ileum of control calf, stained with FITC for $\mathrm{CH} 138+$ granulocytes (green) and with Texas Red for WC1 $\gamma \delta+$ lymphocytes (red). Cell nuclei are stained with DAPI dilactate (blue)

\section{Associations of measured variables with oocyst count}

$\log _{10} \mathrm{OC}_{\max }$ was significantly correlated with three variables $\left(\log _{10} \mathrm{IL}-2\right.$ in ileum, $r=0.829$, $\mathrm{p}<0.001$ (note that log transformation imposes a negative value on IL- 2 but not $\mathrm{OC}_{\max }$ - hence high IL- 2 is associated with lower $\left.\mathrm{OC}_{\max }\right)$; IL-10 in ileum, $\mathrm{r}=$ $-0.553, \mathrm{p}=0.032$; IP-10 in ileum, $\mathrm{r}=0.531, \mathrm{p}=$ 0.034). An additional set of three variables tended to correlate with $\log _{10} \mathrm{OC}_{\max }$ (MHC II cells in ileum, $\mathrm{r}=0.76, \mathrm{p}=0.079 ; \mathrm{CH} 138$ granulocytes in ileum, $\mathrm{r}$ $=-0.74, \mathrm{p}=0.091 ; \log _{10} \mathrm{TNF} \alpha$ in colon, $\mathrm{r}=-0.430$, $\mathrm{p}=0.097)$. The direction of the correlations in log-transformed gene expression data is reversed such that there is a negative correlation between Il-2 and $\log \mathrm{OC}_{\max }$, between IL-10 and $\log \mathrm{OC}_{\max }$, and positive correlations exist between IP-10 and $\log \mathrm{OC}_{\max }$ and $\mathrm{TNF} \alpha$ and $\log \mathrm{OC}_{\max }$.

\section{Discussion}

This study demonstrated that early, mixed infections of $E$. bovis and $E$. zuernii were effectively treated with $15 \mathrm{mg} / \mathrm{kg}$ toltrazuril. It also showed that the use of toltrazuril did not have a statistically significant effect on the pattern and extent of cellular infiltrate into the mucosa of ileum and colon, but that the expression of the genes coding IL- 2 and IL-10 in the ileum and TNF- $\alpha$ in the colon were elevated in calves treated with toltrazuril, consistent with enhanced Th1 and Th2 responses to infection. Nodular change in the colon was associated with higher levels of oocyst production, higher weight loss and higher faecal scores. Nodularity tended to be associated with higher counts of granulocytes, lower CD14 expression and lower TNF- $\alpha$. Higher levels of oocyst shedding were significantly associated with lower expression of genes coding for IL-2, IL-10 and higher IP-10.

In the present study, there was a difference in the inoculating dose of $E$. bovis and E. zuernii. The ratio of $E$. bovis to $E$. zuernii in inoculating doses approximated 3:1 in all cases measured. This mix was a consequence of using a single-passaged field sample as the basis for artificial infections and we believe that it is broadly representative of a natural challenge. Other species seen but not specifically enumerated were presumptively identified as E. alabamensis, E. auburnensis, E. ellipsoidalis and $E$. cylindrica, although these minor species were never more than $10 \%$ of the total count of oocysts and could not be identified with certainty on morphological grounds in all cases.

As expected from previous trials (for example Mundt et al. 2005a), clear and statistically significant differences were evident in the toltrazuril and control groups in faecal oocyst counts, faecal consistency scores and post-mortem findings, consistent with a high level of clinical efficacy of the test product. Efficacy of $99 \%$ (based on arithmetic mean oocyst counts in faeces) was obtained within three days of treatment and maintained at or above this level for six days. The two-day lag in apparent response is expected, given the time required for mechanical clearing of oocysts from the gut. Reappearance of oocysts in the faeces of toltrazuril-treated calves is likely due to the presence of infective extracellular stages of the parasite (sporozoites and merozoites) in the gut at the time of treatment that are not susceptible to the product, since the product is effective only on intracellular stages. 
Mundt et al. (2005a) described the pathology associated with infection by E. zuernii. The major findings 21-26 days post infection included granulocytic infiltration of the mucosa and increased cellular debris, focal damage of the apical villi and the loss of epithelium in some animals. By the time our study was terminated at day 24 post infection, there were only a few meronts to be found and there was evidence of widespread inflammatory cell infiltration into the mucosa of all samples. Varying degrees of disruption of the normal architecture were seen. Grossly evident nodular change and tearing of the mucosa were observed in the colon of some of the control animals but none of the toltrazuril-treated animals. These findings are all in agreement with previous efficacy trials.

There were no significant differences between the control and treatment groups in the immune cell infiltrations in the mucosa of the ileum and the colon. Only a small number of animals (3 of each treatment) were submitted for immunohistochemistry (IHC) and it is possible that this provides insufficient power. However, the numbers of animals used were similar to previous studies (e.g. Hermosilla et al. 1999; Sühwold et al. 2010) and the combinations of high $p$ values and lack of any hint of biologically meaningful trends suggests that the results are likely a legitimate reflection of similar status in the two groups as far as cellular infiltration is concerned. Eosinophils were more common in the ileum and colon of animals classified as resistant, and tended to be associated with higher concentrations of TNF- $\alpha$.

Elevation of the anti-inflammatory cytokine IL-10 associated with toltrazuril treatment is consistent with higher densities of Th2 cells and with the previously identified phenomenon of increased antibody production in chickens infected with
E. acervulina, E. tenella and E. maxima (Greif 2000). In mice infected with $E$. falciformis there was no effect of toltrazuril treatment on specific IgG production. Thus toltrazuril treatment did not impair the parasite-specific antibody-associated immunity (Steinfelder et al. 2005). The elevation of IL-2 seen in the ileum of treated calves in our study would likely be associated with enhanced plasma cell activation as well as cell-mediated immunity, which is thought to be the main effector mechanism of resistance to coccidians (e.g. Sühwold et al. 2010). It is possible that this enhancement of the Th2 response might arise as a result of reduced parasite density and consequent limitation of the innate inflammatory response.

It is concluded that the toltrazuril is effective for the treatment of coccidiosis due to E. bovis and E. zuernii in calves and enables the development of a normal or enhanced Th1 and Th2 response to infection.

\section{Acknowledgements}

The authors wish to thank Tom Connelly, Rose Lederer and Marianne Keller for their assistance with animal management during this trial.

\section{Disclosure statement}

Bayer Animal Health provided financial support for this study. The authors declare that there were no competing interests and that the conceptual design, the conduct, the interpretation of results and all scientific aspects of the study were not influenced by Bayer.

\section{Compliance statement}

All procedures were carried out under the conditions of and with the approval of the University of Queensland Animal Ethics and Experimentation Committee. 


\section{References}

ADAS Manual of veterinary parasitological laboratory techniques (1971) Ministry of Agriculture, Fisheries and Food.

Behrendt JH, Hermosilla C, Hardt M, Failing K, Zahner H, Taubert A (2008) PMN-mediated immune reactions against Eimeria bovis. Vet Parasitol 151:97-109.

Behrendt JH, Ruiz A, Zahner H, Taubert A, Hermosilla C (2010) Neutrophil extracellular trap formation as innate immune reactions against the apicomplexan parasite Eimeria bovis. Vet Immunol Immunopathol 133:1-8.

Bohrmann R (1991) Treatment with toltrazuril in a natural outbreak of coccidiosis in calves. Dtsch Tierärztl Wochenschr 96:343-345.

Bürger H-J (1983) Eimeria-Infektionen bein Rind. Berl Münch Tierärztl Wochenschr 96:350-357.

Collins R, Werling D, Duggan S, Bland A, Parsons K, Howard C (1998) Gammadelta T cells present antigen to CD4+ alphabeta T cells. J Leukocyte Biol 63:707-714.

Daugschies A, Najdrowski M (2006) Eimeriosis in cattle: current understanding. J Vet Med B 52:417-427.

Davis W, MacHugh N, Park Y, Hamilton M, Wyatt C (1993) Identification of a monoclonal antibody reactive with the bovine orthologue of CD3 (BoCD3). Vet Immunol Immunopathol 39:85-91.

Eckert J, Taylor M, Catchpole J, Licois D, Coudert P, Bucklar H (1995) Identification of Eimeria species and strains. In: Eckert J, Braun R, Shirley MW, Coudert P (eds) Guidelines on Techniques in Coccidiosis Research, European Commission, pp 103-120.

Greif G (2000) Immunity to coccidiosis after treatment with toltrazuril. Parasitol Res 86:787-890.

Harder A, Haberkorn A (1989) Possible mode of action of toltrazuril: studies on two Eimeria species and mammalian and Ascaris suum enzymes. Parasitol Res 76:8-12.

Hermosilla C, Burger HJ, Zahner H (1999) T cell responses in calves to a primary Eimeria bovis infection: phenotypical and functional changes. Vet Parasitol 84:49-64.

Jones M, Cordell J, Beyers A, Tse A, Mason D (1993) Detection of $\mathrm{T}$ and $\mathrm{B}$ cells in many animal species using cross-reactive anti-peptide antibodies. J Immunol 150:5429-5435.

Jonsson NN, Gray CP (2007) Coccidiosis in cattle: the role of hygiene and herbicides in its control. Cattle Pract 15:263-266.
Jorgensen WK, Stewart NP, Jeston PJ, Molloy JB, Blight GW, Dalgliesh RJ (1997) Isolation and pathogenicity of Australian strains of Eimeria praecox and Eimeria mitis. Aust Vet J 75:592-595.

Keresztes G, Takacs L, Vilmos P, Kurucz E, Ando I (1996) Monoclonal antibodies detecting components of the bovine immune system in formaldehyde-fixed paraffinembedded tissue specimens. Vet Immunol Immunopathol $52: 383-392$.

Morrison W, Davis W (1991) Individual antigens of cattle. Differentiation antigens expressed predominantly on $\mathrm{CD} 4^{-}$ CD8- T lymphocytes (WC1, WC2). Vet Immunol Immunopathol 27:71-76.

Mundt H-C, Bangoura B, Rinke M, Rosenbusch M, Daugschies A (2005a) Pathology and treatment of Eimeria zuernii coccidiosis in calves: investigations in an infection model. Parasitol Int 54:223-230.

Mundt H-C, Bangoura B, Mengel H, Keidel J, Daugschies A (2005b) Control of clinical coccidiosis of calves due to Eimeria bovis and Eimeria zuernii with toltrazuril under field conditions. Parasitol Res 97:134-142.

Naessens J, Nthale J, Muiya P (1996) Biochemical analysis of preliminary clusters in the non-lineage panel. Vet Immunol Immunopathol 52:347-356.

Shi M, Huther S, Burkhardt E, Zahner H (2001) Lymphocyte subpopulations in the caecum mucosa of rats after infections with Eimeria separate: early responses in naive and immune animals to primary and challenge infections. Int J Parasitol 31:49-55.

Steinfelder S, Lucius R, Greif G, Pogonka T (2005) Treatment of mice with the anticoccidial drug toltrazuril does not interfere with the development of a specific cellular immune response to Eimeria falciformis. Parasitol Res 97:458-465.

Sühwold A, Hermosilla C, Seeger T, Zahner H, Taubert A (2010) T cell reactions of Eimeria bovis primary- and challenge-infected calves. Parasitol Res 106:595-605.

Taubert A, Behrendt JH, Sühwold A, Zahner H, Hermosilla C (2009) Monocyte- and macrophage-mediated immune reactions against Eimeria bovis. Vet Parasitol 164:141-153.

Taylor B, Choi K, Scibienski R, Moore P, Stott J (1993) Differential expression of bovine MHC class II antigens identified by monoclonal antibodies. J Leukocyte Biol 53:479-489. 